\title{
6 The Legitimation of an Authoritative Discourse in Jainism
}

Jain theories of authority (aptatva) can be productively read as reactions to a fundamental philosophical issue - namely, in the situation of the coexistence of two contradictory discourses, both recognized as authoritative by different traditions, what are the means available to distinguish between them? Some of the solutions posed to address this problem of contradiction include consistency with practice, the consensus of a community, the conformity of the discourse at stake with universal laws such as coherence, or appeal to faith or extramundane knowledge.

This paper analyzes the development of critical strategies employed by Jain thinkers to establish the authority of the Jain corpus by refuting theses promoted by competitors from outside of the community. To trace this development, I focus on the Āptamīmāms $\bar{a}$ (Investigation on Authority; $\bar{A} M \bar{i}$ ), composed by Samantabhadra (530-590). This text provides an illustrative case study for my analysis because it marks a transition from a conception in which the reliability criterion of an authoritative discourse is the authoritative character of the speaker, to a conception in which the validity and soundness of the discourse itself are foremost. The text's authorship is also significant, since Samantabhadra is one of the first Jain authors to attempt to logically prove the omniscience of the Jain teachers, and the first one to link this doctrine to the celebrated Jain theory of "non-one-sidedness" (anekāntavāda).

\section{Characteristics of Authoritative Discourse in Jainism}

\subsection{Why Rely on Authoritative Discourse?}

Phenomena that escape our ability to know them are either knowable by ordinary cognition yet out of reach due to a given context, or unknowable by ordinary cognition. Representatives of the first category are the fact that I cannot know the color of Henry IV's horse due to temporal remoteness, nor the trajectory of a butterfly situated on another continent due to spatial remoteness. Likewise, establishing the railway timetables lies beyond my current understanding and knowledge of train traffic, because of an accidental lack of competence in this 
matter. Yet if a competent epistemic agent transfers his knowledge to me, it is then possible for me to have correct knowledge concerning these phenomena. Consenting to rely not only on one's own experience, but on the experience of others as well, is vital and we make constant use of this form of knowledge. To accept that we rely on the knowledge of others does not lessen the importance of personal experience, since indirect knowledge must be assimilated through personal experience. In this dynamic, even the Buddhists, who insist on the primacy of self-knowledge, recognize the importance of reliable instruction.

Examples of the second category - namely, phenomena that transcend human cognition in every context - include the nature of the soul, what happens after death, or the conditions that will cause the end of the world. Knowledge of these phenomena is essential, however, because this knowledge conditions our spiritual progress and realization of a proper human life. Furthermore, unlike a verifiable assertation, such as "quinine cures fever," the assertion that "we gain heaven by virtue" cannot be verified. Therefore, if such assertions are uttered by more advanced epistemic agents, relying on those persons would require new methods of legitimation.

The Jain tradition recognizes the necessity of relying on figures of authority to verify assertations that require extraordinary cognition. Examples of this necessity are presented in the seminal works of Umāsvāti, the Tattvārthasūtra (Treatise on What There Is; henceforth TS) and his commentary on the same work, the Tattvārthasūtrabhāṣya (TSBh), written between $150 \mathrm{CE}$ and $350 \mathrm{CE}$. In these works, Umāsvāti makes the following claims:

TSBh 1.20.15. But knowledge from testimony (śrutajñanam) has the three times as its range and perceives objects that have been produced, that have been destroyed, and that have not [yet] been produced. ${ }^{2}$

TSBh 1.20.23. Knowledge from testimony, due to the quality of being conveyed by allknowing beings and due to the infinity of what is to be known, has a greater range than knowledge by ordinary cognition. ${ }^{3}$

TSBh 1.20.26. It is also for the sake of easy understanding, discerning, reasoning, and the operation of consciousness. ${ }^{4}$

1 These two examples are from Sarvepalli Radhakrishnan, Indian Philosophy, vol. 2 (London: Georges Allen \& Unwin, 1923), 94.

2 śrutajñānaṃ tu trikālavișayam utpannavinaștānutpannārthagrāhakam. The author wishes to address her deepest thanks to Lucas Den Boer, who made available to her the draft of his edition and translation of the TSBh that will be part of his PhD dissertation. The translations of the TSBh used in this article are modifications of Den Boer's translation.

3 sarvajñapraṇitatvād ānantyāc ca jñeyasya śrutajñānaṃ matijñānān mahāvișayam.

4 sukhagrahaṇavijñānāpohaprayogārtham ca. 
These quotes can be interpreted as showing the usefulness of authoritative discourse in the cases of phenomena that are temporally remote, phenomena that are unknowable by ordinary cognition, and phenomena on which a given epistemic agent is not competent, respectively. More importantly, these examples point to a remarkable attitude on the part of Jain philosophers, who collapse the two discrete categories of phenomena knowable by ordinary cognition and phenomena beyond the reach of ordinary cognition into one overarching category. The rationale for this collapsing of categories is that every aspect of the world is, in principle, knowable by human beings. There is no essential epistemic incompetence, but only a transitory, accidental one. Although metaphysical phenomena may exist that elude comprehension through conventional epistemic competencies and limits, human beings are in principle able to evolve and to attain higher epistemic competencies that would allow them to comprehend all phenomena. The aim of this paper is to investigate the consequences of this Jain stance on the methods of validating an authoritative discourse.

\subsection{The Different Types of Authoritative Discourse}

The Tattvārthasūtra is considered the first work of classical, postcanonical Jainism. Its inaugural characterization of an authoritative discourse exhibits a primarily religious and doctrinal perspective. The author's intent is to legitimize the Jain doctrinal corpus, which describes correct faith and knowledge and prescribes correct behavior; rather than an emphasis on the nature and function of the means to gain new knowledge, as one might expect.

This emphasis on legitimizing doctrine has two main consequences for our investigation. First, the kinds of cognition are "distinguished mainly on the basis of the role they play in religious practice." ${ }^{5}$ More specifically, "knowledge by testimony" (śrutajñānam), that is to say, knowledge acquired by relying on the report of speakers endowed with authority, is distinguished from ordinary knowledge because it has a deeper soteriological relevance. Indeed, as we have already mentioned, knowledge by testimony is foremost in this dynamic, because phenomena that transcend ordinary human cognition, such as the soul, are those that condition our spiritual progress toward the realization of a proper human life. ${ }^{6}$ Second, the type of reliable discourses typically considered in Jain

5 Piotr Balcerowicz, "Siddhasena Mahāmati and Akalaṅka Bhațta: A Revolution in Jaina Epistemology,” Journal of Indian Philosophy 44 (2016): 1000.

6 The soteriological relevance of testimony is important insofar that, as remarked by Balcerowicz (see n. 5), knowledge by testimony precedes ordinary knowledge in the classification enumerated 
epistemic treatises of this early stage are not discourses on phenomena knowable by ordinary cognition, yet accidentally out of reach; rather, the focus is on phenomena inaccessible by ordinary perception or reasoning. As a result, (i) the text focuses on teachers who have experienced an epistemic transformation that has granted them extraordinary knowledge; (ii) since it is impossible to verify such statements, the validation of authoritative teaching depends upon the faith one has in the authoritative teachers. For the testimony of such teachers to be classified as valid knowledge requires that the status of the speaker and not the content of the teaching is the condition for validity.

In the following verse from his Tattvārthasūtra, Umāsvāti characterizes testimony as follows:

TS 1.20. Testimony (śruta) is preceded by ordinary cognition (mati). [It consists of] two [varieties], the many [outer limbs], and the twelve [inner limbs]. ${ }^{7}$

There are many classifications of the types of cognition in Jainism. ${ }^{8}$ In the Agamic period (6th century BCE to ca. 4th century CE), five types are recognized: ordinary cognition (mati), testimony (śruta), cosmic knowledge (avadhi), mental knowledge (manahparyāya), ${ }^{9}$ and absolute knowledge (kevala). Then, attempts are made to incorporate Naiyāyika conceptions, especially the distinction between direct and indirect cognition, as well as the classification into perception (pratyakșa), inference (anumāna), analogy (upamāna), and authoritative discourse (śabda). Umāsvāti, who rejects the influence of Nyāya, but nevertheless has to take their contribution to epistemology into account, succeeded in maintaining the traditional fivefold Jain classification by incorporating perception, inference, and analogy into the Jain concept of "ordinary cognition."10 As expressed in TS 1.20, Umāsvāti's definition of authoritative teaching as preceded

in canonical texts such as the Later Chapters, the Uttarādhyayanasūtra (UttS), written in the first centuries CE. See UttS 28.4 in Herman Jacobi, Jain Sūtras, vol.2, Sacred Books of the East 45 (Delhi: Oxford University Press, 1895), 152: knowledge is fivefold: testimony, ordinary cognition, cosmic knowledge, mental knowledge, and absolute knowledge.

7 śrutaṃ matipūrvam dvyanekadvādaśabhedam.

8 This is a specificity of Jainism. While other traditions admit one minimal and clearly defined set of kinds of cognition, Jains admit many types of cognition, and different authors offer different classifications.

9 The traditional translation of "manahparyāya," a perceptual-like awareness of mental phenomena, is "telepathy" or "mind-reading." Lucas Den Boer suggests translating it as "mental perception." In order to go further in the homogenization of the classification, I will adopt the expression "mental knowledge."

10 This is fully developed in Indra Chandra Shastri, Jaina Epistemology, Parshwanath Vidyapeeth Research Series 50 (Varanasi: Parshwanath Vidyapeeth Research Institute, 1990), 196-213. On the 
by ordinary cognition means that acquiring knowledge through the instruction of a reliable person involves first the hearing of a discourse or the perceiving of a text. The knowledge content transmitted by the reliable speaker can in principle come from any type of cognition, that is to say not only from ordinary knowledge, visual or auditive perception, and reasoning, but also from extramundane knowledge such as mental knowledge or absolute knowledge.

What Umāsvāti intended with this definition is not just any type of trustworthy discourse, but rather, the Jain doctrinal corpus itself. The inner limbs he refers to consist of the twelve canonical texts recognized by Śvetāmbara Jains. These are explicitly enumerated by Umāsvāti in his commentary, at TSBh 1.20.10, and include Ācāra, Sūtrakṛta, Sthāna, Samavāya, Vyākhyāprajñapti, Jñātadharmakathāh, Upāsakādhyayanadaśāh., Antakṛdaśāh., Anuttaropapātikadaśāḥ, Praśnavyakarana, Vipākasūtra, and Drștipāta. ${ }^{11}$ As for the outer limbs, they consist of the many texts of the Jain noncanonical corpus. Both types of teaching come from teachers versed in Jain doctrines, although the first type of teaching is more closely related to omniscient "godlike" teachers. According to the tradition, the canonical texts have been taught by the all-knowing Jinas and transmitted to humanity by their pupils, who are the leaders of the respective Jain lineages (ganadhara) and who have supernatural properties. ${ }^{12}$

While Umāsvāti includes both kinds of teaching in his commentary, he clearly puts an emphasis on the teaching of the Jinas. This emphasis is strong enough for him to formulate the following equivalence:

TSBh 1.20.2. Testimony, the words of an authority, scriptural tradition, teaching, tradition, sacred tradition, sacred writings, and the words of the Jinas are synonyms. ${ }^{13}$

In order to better grasp the implications of this equivalence for the definition of authoritative discourse, I now move to discuss the characteristics of these authoritative teachers who are omniscient religious figures.

evolution of the classification of types of knowledge in Jainism, including the status of testimony in them, see also Balcerowicz, "Siddhasena Mahāmati and Akalañka Bhaț̣a."

11 On this topic, the commentary of Pandit Sukhlalji on the Treatise on What There Is is an almost word-for-word exposition, in the form of a discussion, of this part of Umāsvāti's TSBh. This commentary is translated in English in K. K. Dixit, Pandit Sukhlalji's Commentary on Tattvārthasūtra of Vācaka Umāsvāti, Lalbhai Dalpatbhai Series 44 (Ahmedabad: Lalbhai Dalpatbhai Institute of Indology, 1974), 38.

12 TSBh 1.20.21-22.

13 śrutam āptavacanaṃ āgamaḥ upadeśa aitihyam āmnāyaḥ pravacanam jinavacanam ity anarthāntaram. 


\subsection{Characterizing the Authoritative Teacher}

The Nyāyasūtra (Treatise on Logic; NS), a treatise on Naiyāyika obedience written by Gautama around the second century CE, is the interdoctrinal reference work for epistemological considerations in classical India. There, an authoritative discourse is defined in the following terms:

NS 1.1.7. Authoritative discourse is the teaching of a reliable person. ${ }^{14}$

In this seminal definition, the focus on the speaker is evident. This focus will remain in most later works of the pan-Indian epistemological paradigm. The construction of the omniscient teacher as the irrefutable single source of a diverse textual tradition is an effective tool for the philosopher who wishes to establish the validity of his entire doctrinal corpus. Alongside the refutation of selected conceptions of other traditions, Jain, Buddhist, and Naiyāyika philosophers have composed texts that validate the omniscience of their respective founders, and hence of the whole of their respective traditional corpora, the teachings of such extraordinary beings.

Now, one consequence of the fact that authoritative teaching depends upon a person is that it is embedded within the intention of this person, in the sense that no mundane speaker express herself in a decontextualized, universal manner. Yet, testimony is also presented as that which can properly function as an objective means of knowledge (pramāna), that is to say, as knowledge of what exists and not knowledge of a discourse on what exists. It is important to understand that both characterizations, subjective teaching and objective means of knowledge, can coexist only if the teacher has no intention at all, as we will now see.

In the NS, the one teaching authoritative discourse is referred to as apta, the "one who is apt," the "authoritative one." Let us investigate more precisely how this authoritative teacher is described in the Jain tradition. The first Jain to have formally defined the authoritative teacher is Kundakunda. "Kundakunda" is a name that stands for the collective authorship of a textual tradition to which belongs the Niyamasāra (NSā; Essence of Restraints), probably written in the third or fourth to fifth centuries. As Balcerowicz puts it, "traditionally believed by the Digambaras to have flourished in South India sometime before the first and third centuries CE, or even in the first century BCE, Kundakunda is

14 āptopadeśah śabdah. Edited and translated into French in Michel Angot, Le Nyāyasūtra de Gautama Akșapāda. Le Nyāyabhāṣya d'Akșapāda Pakșilasvāmin (Paris: Les Belles Lettres, 2009), 286; translated into English in Ganggānāțha Jhā, The Nyāyasūtra of Gautama with the Bhāṣya of Vātsyāyana and the Vārtika of Uddyotakara, vol.1 (Delhi: Motilal Banarsidass, 1984), 199. 
most probably a collective author to whom a number of works are ascribed. These works, all in Prakrit, were composed, compiled, and expanded on over a span of a few centuries between the late third, early fourth and eighth centuries" and "Kundakunda represents a rare strand within Jainism that lays emphasis on reflection, meditation, and spirituality more than on asceticism and penance." ${ }^{15}$ In his Niyamasāra, Kundakunda characterizes the supreme authoritative teacher in the following way:

$N S \bar{a}$ 5-8. He who is free from all defects and who is possessed of all pure attributes is the supreme authority. The defects are hunger, thirst, fear, anger, attachment, delusion, anxiety, old age, disease, death, perspiration, fatigue, pride, indulgence, surprise, sleep, birth, and restlessness. One free from all these defects and possessed of sublime grandeur such as omniscience is called "the Perfect One." Words proceeding from his mouth, pure and free from the flaw of internal inconsistency, are called verbal testimony (āgama). ${ }^{16}$

A striking feature of this definition is that the authoritative speaker is presented as a godlike entity who has moral aptitudes before he has intellectual ones. ${ }^{17}$ Henceforth, the source of reliable discourse, where "reliable discourse" stands for the Jain corpus, is morally perfect. ${ }^{18}$ His omniscience is mentioned as one

15 Piotr Balcerowicz, "The Philosophy of Mind of Kundakunda and Umāsvāti," in The Oxford Handbook of Indian Philosophy, ed. Jonardon Ganeri (Oxford: Oxford University Press, 2015), 1. 16 vavagayaasesadoso sayalaguṇappā have atto. chuhatạnhabhīruroso rāgo moho cintā jarā rujāmiccu; svedam kheda mado rai viṇhiyaṇiddā jaṇuvvego. ṇissesadosarahio kevalaṇānāiparamavibhavajudo; so paramappā uccai tavvivarīo ṇa paramappā. tassa muhaggadavayaṇam puvvāvaradosavirahiyam suddhaṃ; āgamamidi parikahiyam teṇa du kahiya a havanti taccatthā. Translation from Nagin J. Shah, Akalankk's Criticism of Dharmakirti Philosophy. A Study, Lalbhai Dalpatbhai Series 11 (Ahmedabad: Lalbhai Dalpatbhai Institute of Indology, 1967), 35.

17 On the link between moral and intellectual aptitudes in the discourse on authority in Jainism, as well as in the other traditions of India, see also Jayandra Soni, "The Notion of Āpta in Jaina Philosophy," in South Asian Studies Papers 17. Jain Doctrine and Practice: Academic Perspectives, ed. Joseph T. O’Connell (Toronto: Centre for South Asian Studies, 2000), 55 and 67. 18 This moral requirement, systematically present in Jain texts, can also be found in the Naiyāyika and Buddhist traditions. For example, Candrakīrti (600-650), in his Clarification [on Nāgārjuna's Fundamental Stances on the Way of the Middle], Prasannapadā 268.2, also requires "the removal of all faults" (prahịnāśeșadoșa); see Louis de La Vallée Poussin, Madhyamakavrttiḥ. Mūlamadhyamakakārikās de Nāgārjuna avec la Prasannapadā Commentaire de Candrakirti, Bibliotheca Buddhica 4 (Saint Petersburg: Académie Impériale des Sciences, 1905-1913). For further discussion on the topic, see Vincent Eltschinger, Penser l'autorité des Écritures. La polémique de Dharmakīti contre la notion brahmanique orthodoxe d'un Veda sans auteur. Autour de Pramāṇavarttika 1.213-268 et Svavrtti, Beiträge zur Kultur und Geistesgeschichte Asiens 56 (Vienna: Verlag der Österreichischen Akademie der Wissenschaften, 2007), 80 or Sarah McClintock, Omniscience and the Rhetoric of 
characteristic that appears as a consequence of his state of moral perfection. Some Jain texts that describe the authoritative teacher do not even mention his omniscient character, but focus entirely on the fact that he has annihilated passions. This is the case of the Nyāyāvatâravivrtti (Commentary to the Guide of Logic; NAv), ${ }^{19}$ Siddharșigaṇi's tenth-century commentary on Siddhasena Mahāmati's Nyāyāvatāra (Guide of Logic; NA). We will investigate this later in paragraph 2.2.

The notion that intellectual competency is a correlate of moral competency is rooted in Jain conceptions of the world. More precisely, Jainism has developed within a framework in which virtue is the quality of the one whose acts preserve the best expression of the nature of everything. ${ }^{20}$ Hence, there is no need to postulate an external absolute principle discriminating good acts from bad ones, ensuring that good actions are being pursued, because performing good acts is also performing acts that will enable one to give full expression to her own nature through acts that benefit the individual undertaking them. ${ }^{21}$ Jains also believe that in every living being lies a self whose nature is that of unlimited consciousness. Therefore, realizing the nature of this self by acting in a virtuous, moral way is tantamount to reaching higher epistemic abilities. A metaphor will help to explain this process in more concrete terms. Let's conceive a windowpane through which a landscape can be seen. The presence of a person in front of it causes a reflection that distorts the viewer's vision of the landscape. Karman ${ }^{22}$

Reason. Saantarakșita and Kamalaśila on Rationality, Argumentation and Religious Authority (Boston: Wisdom, 2010), 16. The same holds for the Naiyāyika tradition, originating from the Nyāyasūtrabhāṣya (Commentary on the Verses on Logic; NSBh), composed by Vātsyāyana (450-500). See NSBh 1.1.7. That person is called "reliable," who possesses the direct and right knowledge of things, who is moved by a desire to make known (to others) the things as he knows it, and who is fully capable of speaking of it (āptah khalu sākșātkrtadharmā yathādṛștasyārthasya cikhyāpayișayā prayukta upadeșțā). See Angot, Le Nyāyasūtra de Gautama Akșapāda, 286.

19 NAv 9.1-4 in Piotr Balcerowicz, Jaina Epistemology in Historical and Comparative Perspective (Stuttgart: Franz Steiner Verlag, 2001), 1:50.

20 Such a conception also regularly forms the background of philosophical conceptions in Ancient Greece. The link between morality and the best expression of the nature of something is furthermore present in the use of the term "virtue," which originally comes from the Latin root vir, male force, in the discourse on morality.

21 In a conception of the world in which there is a place for every living entity.

22 There are eight types of karman. Amongst them, only four harmful ones (ghātiyā) obstruct one's omniscience, namely delusory karman (mohaniya), which brings about attachment to incorrect views; karman that obstructs knowledge (jũānāvaraṇiya); karman that obstructs perception (darśanāvaraṇiya); and the obstacle karman (antarāya), which obstructs the innate energy of the soul. 
is the name of such reflections in Jain soteriology, a subtle form of matter that manifests the states of the self and, in doing so, reduces its epistemic potency. By means of ascetic practices aiming at detachment, as described in the Jain canon, it is possible to release the self from this karmic bondage, from wrong acts, acts that are not ultimately good for ourselves, nor for the order of the world, and to become omniscient. In addition, since detachment is the path of this release, moral perfections will be obtained on its course thanks to the removal of passions.

With this in mind, we can understand in greater depth Umāsvāti's characterization of the Jain canonical corpus as what comes from the teaching of the Jinas, the revered spiritual warriors who have reached omniscience. Since the Jinas are liberated beings, they have no passions, which means that they do not interact with human beings and have no intention. Therefore, their teaching emanates from them as a drum emits sound. ${ }^{23}$ This explains why their teaching (i) does not depend upon a given intention and (ii) still needs to be interpreted and codified to be accessible to ordinary human beings.

By contrast, the noncanonical part of the Jain corpus - i.e. those teachings derived from the leaders of Jain lineages who have supernatural properties and from honored Jain teachers - derives from the teaching of beings who still have intentions and can still interact with the mundane world. Yet, as advanced Jain practitioners, they are already thoroughly detached from their passions and, in principle, have no delusive intentions. The moral superiority of the teachers also explains why Jain doctrinal texts are the only source of authoritative discourse. Only Jain texts have authors who cannot be delusive. A teacher who has enough knowledge to be an authoritative teacher has necessarily removed many harmful karman; she is therefore beneficial to other human beings by essence. ${ }^{24}$

23 In his Ratnakaraṇdaśravakācāra (RŚĀ; Manual for the Behavior of Laymen That Is a Jewel Casket), Samantabhadra introduces this eloquent metaphor when he claims that an authoritative teacher who gives instructions does good for people without being motivated by passions, and that he acts for the benefit of humanity on account of his very nature, like a drum emitting sound at the touch of a drummer does not want anything for itself. See $R \hat{S} \bar{A}$ 1.8: anātmārtham vinā rāgaih śāstā śāsti sato hitam. dhvanan śilpikarasparśān murajah kim apekṣate ("Un-egoistically and dispassionately, a teacher instructs from truth what is suitable. What (else) does a muraja drum require to sound but the touch of a skillful hand?"); translation from Willem Bollée, Acarya Samantabhadra Ratnakaraṇdaśravakācāra (Mumbai: Hindi Granth Karyalay, 2012), 15.

24 This can also explain in part the fact that "correct interpretation depends upon a teacherpupil lineage or upon one's own seniority and wisdom"; see Mari Jyväsjärvi, "Retrieving the Hidden Meaning: Jain Commentarial Techniques and the Art of Memory," Journal of Indian Philosophy 38 (2010): 135. 
As the Naiyāyikas remind us, for a discourse to be reliable, it does not suffice for its teacher to be epistemically and morally competent; he also has to be linguistically competent. Vātsyāyana (450-500) makes this assertion in his Nyāyasūtrabhāṣya (Commentary on the Verses on Logic; NSBh), in which an authoritative person is described as possessing direct and correct knowledge of things; as being moved by a desire to make known the things as he knows them; and as being fully capable of transmitting this by means of language. Another peculiar feature of Jainism is that in the case of omniscient beings, this linguistic competency is transferred to other beings also endowed with higher epistemic abilities. The intellectual and moral competency of the Jinas transcends human abilities, but linguistic competency is the only one that human beings can access. ${ }^{25}$ This explains the importance of theories of interpretation, and especially hermeneutics, in Jain philosophy. As Jyväsjärvi puts it, "the commentaries are regularly more important than the canon itself." 26

\section{The Legitimation of Authoritative Discourse}

\subsection{Choosing Reliability Criteria}

In the pan-Indian tradition, the importance of the authoritative teacher is such that when attempting to establish the authoritative character of a discourse, Jains, as well as Naiyāyikas and Buddhists, first seek to establish the authoritative character of the speaker. We have seen that this is the case in the classical tradition of Jain epistemology, with Umāsvāti and Kundakunda focusing on the special qualities of the speaker. An interesting shift in Jain epistemology occurs with Siddhasena Mahāmati (720-780). His Nyāyāvatāra (Guide of Logic; $N A$ ), is the first Jain work to have a completely epistemic perspective, independent of devotion and tradition. In his work, authoritative discourse is defined as follows:

$N A$ 9. An authoritative treatise is that which has been discerned by an authoritative person, which is not negligible, which does not contradict what is accepted or what is

25 Incidentally, the sections on authority are usually the occasion for philosophers to develop their theories of meaning (the relation between words and objects).

26 Jyväsjärvi, "Retrieving the Hidden Meaning," 135. 
experienced, which gives the instruction about reality, which is for everybody and which obliterates errant paths. ${ }^{27}$

The first part of the definition establishes an authoritative treatise as the product of the knowledge of an authoritative person. This definition clearly aligns Jain conceptions of authority with the Treatise on Logic's tradition of Naiyāyika obedience, in which the teacher with special powers is the keystone of reliable discourse. Authoritative teaching is still defined in terms of a doctrinal corpus, a "treatise" (śāstra), and not an isolated, albeit correct claim about an unknown phenomenon. The shift occurs in the second half of the definition, when it is claimed that in order to be recognized as authoritative, a teaching must satisfy a list of criteria of soundness. In other words, "it is not tradition as such that becomes a distinct source of knowledge, but rather a tradition that has been systematised as a result of reasoned enquiry." 28 To sum it up, considerations on authoritative teaching in Jainism started at an early stage as an attempt to present tradition as an efficient means to acquire knowledge of the world. As such, authoritative teaching is distinct from ordinary cognition because only special seers could evaluate its correctness. Authoritative teaching then evolved as an attempt to validate a doctrinal corpus that is the product of regulated reasoning as an efficient means to acquire knowledge of the world. As such, it is not distinct from ordinary cognition, because in this conception, testimony can be verified thanks to a competent use of sense faculties and reason combined. In this conception, the means to evaluate authoritative character do not principally rely on the characterization of its speaker.

Of course, the requirement that an authoritative set of assertions must stand the test of reason is not a novel claim by Siddhasena, but is found from in Jainism a very early stage. In fact, Bhadrabāhu (ca. 1st and 5th century CE), in his Daśavaikālikaniryukti (Considerations on the Ten Evening Devotions; DVN), is the sole Jain author to claim that authoritative scriptures (ägama) stand in no need of establishment by means of reasoning; they are infallible, and reasoning is only necessary to elucidate their meaning. ${ }^{29}$ But besides this notable exception, already in Jain paracanonical texts of the early first centuries, contradiction

27 āptopajñam anullanghyam adṛșteșțavirodhakam. tattvopadeśakṛt sārvaṃ śāstram kāpathaghațtanam. Translation from Balcerowicz, Jaina Epistemology in Historical and Comparative Perspective, 50. Also quoted in Eltschinger, Penser l'autorité des Écritures, 105.

28 Puruṣottama Bilimoria, Śabdapramāṇa: Word and Knowledge, Studies of Classical India 10 (Dordrecht: Kluwer, 1988), 9; emphasis is mine.

29 Shah, Akalanika's Criticism of Dharmakirti Philosophy, 36. 
(vāhasya), the property of not being correct (ayukta), and contradiction with one's own doctrine (samaya-viruddha) are among the faults of a sacred text. The fact that a sacred text possesses reason (hetu-yukta) is considered one of its strong points. ${ }^{30}$ Likewise, classical authors focusing on the speaker also recognize internal consistency and consistency with other types of cognition as a special feature of the sacred text. See, for example, Kundakunda on his own teachings in his Samayasāra ${ }^{31}$ (Essence of the Self; SSā):

SSā 5. I will try to reveal the nature of the Self as far as I can. Accept it if it satisfies the conditions of truth of the types of knowledge (pramāna). But if I fail in my description, you may reject it. $^{32}$

But, as is most apparent in Kundakunda, standing the test of reason is second to the authority of the speaker:

$N S \bar{a}$ 8. Words proceedings from his [i.e. the authoritative speaker, free from defects] mouth, pure and free from the flaw of internal inconsistency, are called verbal testimony $(\bar{a}$ gama $){ }^{33}$

And this is only from Siddhasena that the sacred scriptures are not mainly established thanks to the special properties of the speaker. A similar position is held by Akalanika Bhațta (720-780), a younger contemporary of Siddhasena Mahāmati. ${ }^{34}$ Akalañka, as quoted by Prabhācandra (980-1065) in the Nyāyakumudacandra (Moon on the Lotus of Logic; NKC), claims,

NKC 632: Reliable teaching is not opposed to other kinds of cognition and does not contradict the doctrine. ${ }^{35}$

30 Nalini Balbir, "The Perfect Sūtra as Defined by the Jains," Berliner Indologische Studien 3 (1987): 9.

31 In this work, from "conventional definition" to "correct definition [of the Self]," samaya came to mean "the Self in its true nature."

32 tam eyattavibhattam dāyeham appaṇo savihaveṇa. jadi dāyejja pamāṇam cukkijja chalam na ghettavvam, edited in Appaswami Chakravarti, Ācārya Kundakunda's Samayasāra (New Delhi: Bharatiya Jnanpith, 1950), 189.

33 tassa muhaggadavayaṇaṃ puvvāvaradosavirahiyam suddhaṃ. āgamamidi parikahiyam teña dukahiyāhavamnti taccatthā, edited and translated in Uggar Sain, Niyamasāra (The Perfect Law) by Sri Kundakunda Ācārya, Sacred Books of the Jainas 9 (Lucknow: Central Jaina Publishing House, 1931), 4.

34 For the dating of these two authors, see Balcerowicz, "Siddhasena Mahāmati and Akalañka Bhațta," 2.

35 śruteh pramānāntarābādhanaṃ pūrvāparāvirodhaś ca avisaṃvādaḥ, edited in Mahendra Kumar Nyāyācārya, Prabhācandra's Nyāyakumudacandra. A Commentary on Bhaț̣ākalanikadeva's Laghìyastraya (Bombay: Manikacandra Digambara Jaina Grantha Mālā, 1941), 2: 632. Also edited 
After Akalankka, Jain philosophers built on the innovative work of the Buddhist philosopher Dharmakīrti ${ }^{36}$ (550-610). ${ }^{37}$ In his Pramānavarttika (Verses on Knowledge; PV) and Pramānavārttikasvavṛtti (PVsV), Dharmakīrti, himself building on his contemporary Kumārila's criticism of omniscience, insists that neither perception nor inference can give us access to the mental properties of other people. He concludes that a human being is unable to distinguish an authoritative teacher from a nonauthoritative one. ${ }^{38}$ This, in turn, makes "being authoritative" (aptatva) a useless quality when what is at stake is to evaluate the reliability of a given set of assertions.

Confronted with this argument, thinkers from this major early Indian school of thought attempted to identify a standard for reliability that did not depend on the perfection of the speaker, but on the soundness of the corpora of authoritative assertions (śāstra) themselves. Dharmakīrti, expanding on ideas found in Pakșilasvāmin, Dharmapāla, and Bhāvaviveka, provides a systematic account of these criteria in his PV 1.108-109. First of all, a treatise must be worthy of evaluation, which means that it must be consistent, appropriate to the result it strives to attain, and have one of humankind's goals as its object. If a treatise merits study, we can ask ourselves whether it is prudent to regard it as reliable. As a test of reliability, one may strive to determine whether the propositions are verifiable (i.e. respectively falsifiable) by means of mundane types of knowledge. More concretely, (i) perception helps us to evaluate the textual passages concerning perceptible objects by establishing whether statements from the evaluated treatise are in accordance with what one experiences and sees; (ii) inference based on states of affair helps us to evaluate the sections concerning nonperceptible objects by establishing whether statements from the evaluated treatise are in accordance with what the laws of rationality enable us to infer from what one experiences and sees; and (iii) inference based on scriptures (āgamāpekșānumāna) helps us to evaluate sections concerning radically nonperceptible objects - that is to say,

in Akalankagranthatraya (The Sum of Akalarika's Three [Treatises]), in Mahendra Kumar Shastri, Akalankkagranthatrayam of Sri Bhațākalañkadeva, Saraswati Oriental Series 8 (Ahmedabad: Saraswati Pustak Bhandar, 1939).

36 See for example Eltschinger, Penser l'autorité des Écritures, 59 : "Pour le Mīmāṃsaka, le Veda fait autorité parce qu'il n'a pas d'auteur; pour le naiyāyika, le jaïniste, le sivaïte ou la plupart des bouddhistes eux-mêmes, l'Écriture fait autorité parce que son énonciateur possède telles ou telles qualités. [. . .] la doctrine méta religieuse de Dharmakīrti invite au contraire à rechercher le critère de l'autorité dans l'Écriture elle-même, l'autorité de son auteur n'étant au mieux que dérivée."

37 For this dating of Dharmakīrti, see Piotr Balcerowicz, "On the Relative Chronology between Samantabhadra and Dharmakīti,” Journal of Indian Philosophy 44 (2016), 437-483.

38 PV 2.218-219. 
nonverifiable propositions - by establishing whether statements from the evaluated treatise are in accordance with what authoritative teachers have said. ${ }^{39}$ Suggesting such a method, Dharmakirti is also aware of another tradition, namely the Naiyāyika one. Indeed, in his Nyāyasūtrabhāṣya, at NSBh 1.1.8, Vātsyāyana employs a similar strategy to evaluate reliability. He claims that, since the assertions of sages (rși) on mundane matters (drșțārtha) - their Ayurveda prescriptions and Vedic mantras - were consistently deemed to be true, we should act from the assumption that their assertions on extramundane matters (adrșțārtha), like parts of Veda concerning cosmic order (dharma), are also reliable. ${ }^{40}$

It is evident that Siddhasena Mahāmati and Akalanka place their teachings within this pan-Indian epistemological tradition, as evinced by their claims in NA 9 and NKC 632 (quoted above) that an authoritative discourse is a traditional text that has been systematized as a result of reasoned inquiry.

\subsection{The Problem of a Speaker's Intention}

The fact that Jain philosophers of this period share this method to evaluate reliability with the Buddhists and the Naiyāyikas does not mean that they share all the premises that support it. Akalanka, in particular, strives to prove that the use of these rational criteria to evaluate the reliability of an authoritative discourse does not necessarily mean that it is impossible to infer the intention of its speaker. In fact, the Jain tradition specifies that the intention of a speaker can be inferred by means of reasoning from observation. More precisely, in his Aștaśatī (Eight Hundred Verses; AŚ), Akalañka defends the thesis that states "a well-examined overt behaviour would always enable us to infer its cause, the internal quality. It is a rule that a well-scrutinised effect would never frustrate our efforts to infer its proper cause."

While it is hard to determine precisely the conception of Jain philosophers concerning the nature of the states of the soul, it is clear that laws of causality apply to these states. Furthermore, these states are expressed within a karmic network, which is a type of subtle matter upon which physical laws apply. In this conception, the apparent inaccessibility of the intention of a speaker is merely due to the complexity of the situation to untangle, but mundane types

39 Eltschinger, Penser l'autorité des Écritures, 105 on PVsV 1.109.1-3.

40 This is developed for example in Radhakrishnan, Indian Philosophy, 2:94 and in Eltschinger, Penser l'autorité des Écritures, 96.

41 AS 72 as quoted by Shah, Akalanka's Criticism of Dharmakirti Philosophy, 286: yatnatah parīkṣitaṃ kāryam kāraṇaṃ nātivartata iti cet stutam prastutam. 
of knowledge can be used to track back the causal chains of these phenomena. Of course, also extramundane types of knowledge, especially the direct perception of these subtle elements, are available to the advanced Jain. This last fact is well documented both in theoretical treatises and in literary texts, as is made apparent by the following description from Cort: "like any mendicant who is far advanced on the Jain spiritual path, Sudharman ${ }^{42}$ had the ability to see the hidden karmic state of the soul of other living beings, and so could reveal to anyone his or her true condition." ${ }^{43}$ Here, we see that even mundane types of knowledge can be used to evaluate a given karmic network and, in doing so, the equivalent state of the soul.

\section{Samantabhadra: A Specifically Jain Way to Establish Authority}

\subsection{Between Different Reliability Criteria}

Akalanka's thesis on the knowability of intention can be found in a commentary on the Āptamìmāmsā (Investigation on Authority; $\bar{A} M \bar{i}$ ) of Samantabhadra (530-590). ${ }^{44}$ Three important authors have commented on the $\bar{A} M \bar{i}$ : namely, Akalanka in the work just quoted, the Aștaśatī, Eight Hundred Verses (AŚ); Vidyānandin in the Aștasahasrī (AS), Eight Thousand Verses, 940; and Yaśovijaya in the Aștasahasrivivaraṇa (ASV), Explanation of the Eight Thousand Verses (1688). There is also one commentary by a Vasunandi, namely the Aptamimāmsāvrtti $(\bar{A} M \bar{i} V)$, the Commentary on the Investigation on Authority (8th c.). The $\bar{A} p t a m \bar{m} m \bar{a} m s \bar{a} v r t t i^{45}$ is an interesting case for the present study because

42 Sudharman, a follower of Mahāvira, is a leader of a lineage (gaṇadhara) believed to have supernatural powers, and he is considered a father of the community by Śvetāmbara Jains.

43 John Cort, "An Epitome of Medieval Śvetāmbara Jain Literary Culture. A Review and Study of Jinaratnasūri’s Līlāvatīsāra,” International Journal of Jaina Studies 5, no. 1 (2009): 5.

44 Balcerowicz, "On the Relative Chronology between Samantabhadra and Dharmakirti," develops a proof that Samantabhadra is after Dharmakirti, which redefines Dharmakirti's dates.

45 The Investigation on Authority is traditionally considered to be the commentary on the opening benediction (mañgalācaraṇa) of Umāsvāti's On What There Is, which is meant to salute the Jinas, by stating "I bow to him who is the guide on the path to liberation, the destroyer of mountains of karman and the knower of the principles of the universe, so that I may attain these qualities belonging to him" (mokșamārgasya netāram bhettāram karmanbhūbhṛtām, jñātāram viśvatattvānām vande tadguṇalabdhaye); see Saratchandra Ghoshal, Āptamīmāmsāa of Ācārya Samantabhadra (New Delhi: Bharatiya Jnanpith, 2002), 8. 
Samantabhadra's conception is a combination of Jain elements present in preDharmakìrti, as well as in post-Dharmakīrti frameworks. In the rest of this paper, I will focus on Samantabhadra's work for three main reasons. First, because it offers a relevant case study with which to investigate the transition from a conception in which the reliability criterion of an authoritative discourse is the authoritative character of the speaker, to a conception in which the criteria of validity and soundness of the discourse itself are foremost; second, because Samantabhadra is one of the first Jain authors to undertake to logically prove the omniscience of the Jain teachers; and third, because he links these questions to the celebrated Jain theory of non-one-sidedness (anekāntavāda).

The following verse could lead us to think that for Samantabhadra, the soundness of a discourse is a criterion for validity:

$\bar{A} M \overline{1}$ 1.6. Only you, whose words are unopposed to logic, perception, and scriptures, are free from all faults, because what it is you desire is not opposed to proof. ${ }^{46}$

However, Samantabhadra does not claim in this verse that scriptures are authoritative because they are consistent with reason and perception. Rather, he claims that consistency with reason and perception is the external sign of the presence of an authoritative speaker. The authority of the speaker is, in turn, the effective validating criterion of the authoritative character of a given discourse. In his Așțasahasrī, Vidyānandin comments on the above verse, arguing that it must be understood in light of the latter's devotion to the Jina Sambhava, the third awakened Jain teacher who had become omniscient and freed of passions in the current cosmic age. ${ }^{47}$ Samantabhadra has compared Sambhava to a physician: just as a physician helps people to be cured by a combination of reasoning and knowledge of medical treatises, in the same way, an awakened Jain teacher helps people to free themselves from the cycle of reincarnation by means of teachings that are, by nature, in accordance with both reasoning and the scriptures. In this conception, the internal (consistence of the discourse itself with reason and perception) and external (authoritative character of the speaker) criteria used to establish an authoritative discourse are intertwined.

In this framework, it becomes important to precisely enunciate the properties that make a speaker an authority. In the $\bar{A} M \bar{i}$, this issue is tackled through Samantabhadra's attempts to enunciate the properties of the omniscient teacher. First, Samantabhadra is careful to specify the properties that cannot be used to

46 sa tvam eva āsi nirdoṣo yuktišāstrāvirodhivāc. avirodho yad ișțạ̣ te prasiddhena na bādhyate. In his commentary on this sentence in $\bar{A} M \bar{i} V$ 6.18-19, Vasunandi analyzes yukti as meaning "inference and perception."

47 See Ghoshal, Āptamīmāmssā of Ācārya Samantabhadra, 46. 
determine omniscience. These include extraordinary acts, extraordinary properties, and prophecy. These acts are not sufficient to prove the omniscient character of a teacher, since extraordinary acts can be imitated by magicians ${ }^{48}$; some superior beings endowed with extraordinary external and internal properties do still have passions, and harmful karman ${ }^{49}$; and non-Jain teachers such as Kapila and the Buddha offer contradictory teachings, which is proof that they are not omniscient. ${ }^{50}$ It is in $\bar{A} M \bar{i} 4$ that Samantabhadra delineates the essential properties of an omniscient teacher, namely the total destruction of karman. ${ }^{51}$ Claiming this, he defends the traditional Jain thesis. What is interesting for us in this argument is the metaphor Vasunandi uses to comment on this verse. He likens the removal of karman to the act of "the purifying of a piece of metal of gold which might have external impurities like mud, etc. attached to it and internal impurities like alloy mixed with the same. By washing or scouring we can do away with the external impurities and by melting we can destroy the alloy bringing out the pure gold. In a soul also karman internally obstruct right knowledge." 52 I claim that we can take this literally enough to understand that the removal of karman follows physical

$48 \bar{A} M \bar{i} 1$. The miraculous attainments like an attendance offered by the celestial beings, a walk in the sky, a fan service (worked by the celestial beings), and so on and so forth are found in the possession of even jugglers; these (miraculous attainments, which you certainly possess) are (therefore) not what make you great in our eyes (devāgamanabhoyānacāmarādivibhūtayah, māyāvișvapi dṛ́syante nātastvamasi no mahān). Edited and translated by Nagin J. Shah, Samantabhadra's Āptamīmāmsā. Critique of an Authority. Along with English Translation, Introduction, Notes and Akalañka's Sanskrit Commentary Așțaśatī, Sanskrit-Sanskriti Granthamālā 7 (Ahmedabad: Jagruti Dilip Sheth, 1999): 1.

$49 \bar{A} M \bar{i}$ 2. The divine excellence of body, etc. - an excellence that might be of an internal or external sort - is a genuine possession of even the denizens of heaven who are (by nature) under the sway of the spiritual deficiencies like attachment, etc. (adhyātmam bahirapyeșa vigrahādimahodayah, divyaḥ satyo divaukassvapyasti rāgādimatsu saḥ); Shah, Samantabhadra's Āptamìmāms ā, 2.

$50 \bar{A} M \bar{i} 3$. As for the preaching of the various sect founders, they cannot be all authentic because they are mutually contradictory; (hence) of these sect founders, someone at the most can be worthy of reverence (tìrthakrtsamayānām ca parasparavirodhatah, sarveșāmāptatā nāsti kaścideva bhaved guruḥ). See Shah, Samantabhadra's Āptamīmāmsāa, 2.

$51 \bar{A} M \bar{i}$ 4. The total destruction of faults and impediments [to perfect knowledge of the Self] occurs because excellence [in this gradual process toward the completion of the Self's own nature occurs], just as the external and internal impurities of a thing are wiped out when the appropriate methods are used (doṣâvaranayor hānir niḥseșā'sty atiśāyanāt, kvacid yathā svahetubhyo bahir-antar-mala-kșayah). Edited in Shah, Samantabhadra's Āptamīmāmsāa, 3; my translation.

52 Ghoshal, Āptamīmāmsāa of Ācārya Samantabhadra, 36; edited in Pandit Pannalal Jain Bakaliwal, Śr̄̄samaṃtabhadrasvāmiviracitā Āptamīmāmssā syādvādavidyāpatiśrīvidyānaṃdasvāmiviracitā Pramāṇaparīkṣā ca, Sanātanajainagranthamālā 10 (Vārāṇasī: Jaina Grantha Mālā, 1914). 
laws and that a theory of the precise mechanism of this removal is possible. Interestingly enough, the metaphor of the gold is also the one used in the Buddhist tradition of the same period to refer to the (direct) criteria of the reliability of a discourse. Indeed, the Buddhists Sāntarakșita (725-788) and Kamalaśīla (740-795) comment on Dharmakīrti's three tests of the reliability of an authoritative discourse by claiming that, just as we can determine whether something is pure gold or not by means of calcination, abrasion, or rubbing it on a touchstone, in the same manner, we can determine whether something is an authoritative teaching by means of perception when the authoritative treatise deals with perceptible objects, inference when it deals with contextually nonperceptible objects, and noncontradiction with what is already established when it deals with essentially nonperceptible objects.

\subsection{Proving the Existence of an Omniscient Jain Teacher}

In his $\bar{A} M \bar{i}$, Samantabhadra not only characterizes the omniscient Jain teacher, but also advances a proof of her existence. ${ }^{53}$ According to him:

$\bar{A} M \bar{i}$ 5. The objects that are minute, concealed, or distant must be amenable to somebody's perception, because they are amenable to inferential knowledge, just like fire, etc. It is this argument that establishes the existence of an omniscient personage. ${ }^{54}$

I summarize the argument as follows: the common way to establish inference is to have recourse to a previously perceived situation that displays a paradigmatic example analogous to the one under investigation. The traditional example is that of the smoke and the fire, in which I am able to infer the presence of an unperceived fire from the perception of a type of smoke, because there are former analogous paradigmatic situations in which smoke of this type has been seen with a fire underneath it. In other words, inference is accepted in situations of nonperception only if it is possible to draw a link to

$53 \mathrm{He}$ is usually presented as the first philosopher to do so. More on this topic in Olle Qvarnström,“The Jain-Mīmāṃsā Debate on Omniscience,” in Studies in Jaina History and Culture. Disputes and Dialogue, ed. Peter Flügel (London: Routledge Advances in Jain Studies, 2006), 89-106.

54 sūkṣmāntaritadūrārthāḥ pratyakșāḥ kasyacid yathā, anumeyatvato’gnyādiriti sarvajñasamsthitiḥ, (Shah, Samantabhadra's Āptamimāmssā, 4). This argument is also translated and commented on in Sin Fujinaga, "Determining Which Jaina Philosopher Was the Object of Dharmakīti's Criticisms," Philosophy East and West 50, no. 3 (2000): 378-384, and Fujinaga, "Why Must There Be an Omniscient in Jainism?” in Studies in Jaina History and Culture. Disputes and Dialogue, ed. Peter Flügel (London: Routledge Advances in Jain Studies, 2006), 107-116. 
another specific situation in which phenomena of each type involved were actually perceived. ${ }^{55}$ Therefore, every time an inference is justified, there exists at least one situation in which objects of the same type as the objects involved have actually been perceived by someone.

But this argument is not sufficient to conclude that inferences about objects that are not perceivable by mundane faculties have necessarily been perceived in some way or another, for example by means of extramundane perception like that of a yogin. To explain, it is possible to acquire knowledge concerning phenomena that are inaccessible to mundane perception through inference by analogy. With inference by analogy, for example, it is sufficient to have already perceived a paradigmatic case of relationship between an effect and its cause - e.g. the perception of the breaking of a cup because of its falling on the ground can be sufficient - in order to be able to deduce from this a list of the characteristics of the cause-effect relationship in general, and to then infer the characteristic of a transcendental cause. From this, the only way to understand Samantabhadra's argument is to say that the range of legitimate inferences on the nature of the world is so wide and all-pervasive that only the existence of an omniscient teacher can guarantee that in any case the direct perception of one instance of the related phenomena or of one instance of this type of relation is possible. As mentioned earlier, Jain philosophers believe that the two categories of phenomena - knowable by ordinary cognition yet accidentally out of reach, and unknowable by ordinary cognition - come down to one category, inasmuch as every aspect of the world is, in principle, knowable by human beings.

\subsection{Authoritativeness of the Jain Corpus and the Non-one-sidedness of Things}

Samantabhadra's next step is to advance a third, and specifically Jain, method of discriminating between reliable and nonreliable teachings. This method, which retains Samantabhadra's attention for the rest of the Aptamimāms $\bar{a}$, is based on the following judgment:

$\bar{A} M \bar{i} 7$. Those who are alien to your nectarlike doctrine are the upholders of utterly extremist theses; they are the victims of their own vainglorious claims to be an authority (on the

55 This is, by the way, the key defense of Jain and Buddhist philosophers who try to refute the Naiyāyika proof of the existence of God. More precisely, when the Naiyāyikas try to argue that whenever there is an effect, there is a conscious cause involved at some point in the process of production, the Jains and Buddhists will counterattack by pointing to the fact that no human being has ever experienced a situation in which the growing of the grass was involving at some point the activity of a consciousness. 
subject matter they deal with); they are persons who seek to establish something that is contradicted by what is seen to be the case. ${ }^{56}$

Understanding this verse presupposes some knowledge of the Jain theory of non-one-sidedness (anekāntavāda) and of viewpoints (nayavāda). According to these theories, the object of knowledge is fundamentally complex and human epistemic faculties tend to resolve this complexity by subsuming diversity within a larger unity. Human knowledge functions by recognizing familiar features or patterns. Without this, nothing would be intelligible, nor communicable. In this process of subsuming diversity within unity, it is possible to create a continuum ranging from specific to more general categories. For example, we can describe something according to the general category "green," the more specific "olive green," or even list a series of chemical components that create the color. This plurality of possible valid and specific types of attention to the knowable is also what explains the existence of different philosophical attitudes, especially in consideration of the primary problem of the articulation of the one and the many. In consequence, there is a favored type of attention that is active during the construction of any body of knowledge and human beings necessarily state their knowledge in dependence on a set of presuppositions of which they are not aware, and that determine the very scope and meaning of their knowledge statements. The Jain theory of viewpoints is precisely the specification of the main types of epistemic attention active in the elaboration of these presuppositions. It is a metatheory of knowledge that offers a classification of the great types of theories of knowledge, called "viewpoints" (naya). With this theory, Jains are able to explain the specific aptitudes, as well as the specific limits, of every historical philosophical tradition of India. For example, the viewpoint called "collective viewpoint" (samgrahanaya) brings together all the theorists who believe that the single robust reality, the one that is not subjected to change, is a permanent reality that includes everything. Theorists of Advaita-Vedānta, as well as theorists of Sāṃkhya, are representative of this viewpoint because they excel at identifying the imperceptible connections and unity underlying the diversity of objects of knowledge. They especially understand how everything is a manifestation of the same spiritual substance. Moreover, they believe it is only due to the structure of the human mind that we consider things as being independent entities. Yet, at the same time, they fail to understand the

56 tvanmatāmṛtabāhyānām sarvathaikāntavādinām, āptābhimānadagdhānām sveșțaṃ dṛștena bādhyate; see Shah, Samantabhadra's Āptamīmāms āa, 6. 
fundamental differences between the types of objects of knowledge. In opposition to this epistemic stance, the "direct viewpoint" (rjusūtranaya) brings together all the theorists who believe that the single robust reality is the less possible inclusive reality, the one that persists neither in space nor in time. Buddhist thinkers are representative of this viewpoint, because they excel at identifying the transitory character of objects of knowledge as well as the epistemic constructions active when operations of synthesis are performed during the knowledge process. However, they fail to understand the fundamental elements of permanence in these objects of knowledge.

Let us now return to the seventh verse of the Áptamimāmsā, namely "those who are alien to your nectarlike doctrine are the upholders of utterly extremist theses; they are the victims of their own vainglorious claims to be an authority (on the subject matter they deal with); they are persons who seek to establish something that is contradicted by what is seen to be the case." In this verse, "what is seen to be the case" is non-one-sided objects. The argument is that, since a knowable entity is always multifaceted, the Jain corpus, which recognizes the non-onesided essence of the knowable, is not opposed to perception, inference, or the other types of knowledge. What I would like to stress here is that it was the need to establish the authoritative character of a teacher that led Samantabhadra to the theory of non-one-sidedness in this work. Samantabhadra's method to establish the validity of the Jain corpus was to systematically refute the assertions of nonJina teachers by means of showing that these are one-sided assertions. A large part of the Āptamimāmsā is directed toward these refutations, which can be read as a model that could be used to refute other seemingly absolute assertions.

Here, it seems that in order to establish the authority of the Jain corpus and doctrine, Samantabhadra could have used Dharmakirti's direct method to prove that the Jain corpus is taught by an authoritative person because it is in accordance with perception and inference and it is coherent. Instead, Samantabhadra aims to establish the authority of the teaching of the Jinas. This special teaching calls for a special methodology because one has to refute the fact that a given assertion can be established in an unconditioned way. Samantabhadra cannot himself establish an assertion directly in an unconditioned way, otherwise it would contradict this very thesis and no thesis is ultimately established. In this situation, refuting everything that is opposed to the teaching of the Jinas is actually the only efficient strategy. ${ }^{57}$

57 The Buddhist Nāgārjuna is famous for having faced a similar situation when he aimed to refute the fact that an ultimate assertion could be made without making such an ultimate claim himself, and for having adopted a similar strategy when he undertook to refute any ultimate assertion he encountered. 


\section{Conclusion}

In their efforts to define the nature, scope, and reliability of authoritative teaching, Jain philosophers were building on pan-Indian conceptions of this matter while also expressing their fundamental specificities of the Jain conception. First, pan-Indian theories of authoritative teaching include (i) a primary focus on sacred texts; (ii) a primary focus on the omniscient source that emits this nonfalsifiable body of teaching; (iii) a soteriology enabling the acquisition of extramundane epistemic faculties; and (iv) an epistemological turn around the sixth century promoting reasoned inquiry. In this framework, Jain philosophers go further than philosophers from other systems concerning the recognition of human epistemic abilities. Indeed, there is no essentially unknowable state of affair in Jainism, not only because human beings are omniscient in principle and some advanced Jains are omniscient in fact, but also because phenomena that are seemingly inaccessible to mundane knowledge follow the laws of causality and karman is a concrete substance that follows the laws of physics. Second, there is a multitude of omniscient Jinas and of teachers with extramundane epistemic faculties. Third, when refuting the theses of other traditions, the Jain Samantabhadra makes use of a specific type of refutation that consists in showing the ultimate inadequacy of any one-sided view and, at the same time, establishes the Jain doctrine of non-one-sidedness. This strategy is not only mandatory for the one avoiding the "contextually valid" labeling of his own claims, but it is also an efficient strategy for survival in the case of a minority tradition like Jainism. Indeed, this insistence on the contextual validity of every claim not only resolves apparent contradictions between Jain conceptions and the conceptions of others, but also provides Jainism an intellectual authority over other traditions. ${ }^{58}$

\section{Primary Sources}

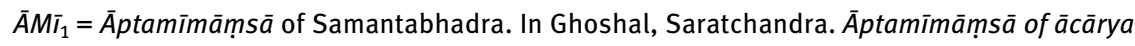
Samantabhadra. New Delhi: Bharatiya Jnanpith, 2002.

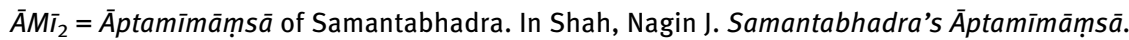

Critique of an Authority. Along with English Translation, Introduction, Notes and

58 In the words of Qvarnström, "the fact that the Jains, through such theories of perspectives, were both difficult to influence, and, at the same time, sympathetic towards others, made them perhaps also better equipped to cope with matters challenging their survival and growth” (“The Jain-Mīmāṃsā Debate on Omniscience,” 35). 
Akalañka's Sanskrit Commentary Aștaśatī. Sanskrit-Sanskriti Granthamālā 7. Ahmedabad: Jagruti Dilip Sheth, 1999.

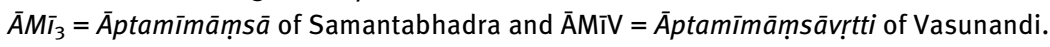

In Pandit Pannalal Jain Bakaliwal. Śrīsamaṃtabhadrasvāmiviracitā Āptamīmāṃsā syādvādavidyāpatiśrīvidyānaṃdasvāmiviracitā Pramānaparīkșā ca.

Sanātanajainagranthamālā 10, Vārāṇasī: Jaina Grantha Mālā, 1914.

$\bar{A} \hat{S}=$ Aștaśatī of Akalañka Bhațța, $A S=$ Așțasahasrī of Vidyānandin, and ASV = Aștasahasrīvivarana of Yaśovijaya. In Baṃsīdhar, Bhatt. Așțasahasrī of Vidyānandin on Aștaśatī of Akalañka. Sholapur: Gandhī Nāthārarājī Jaina Granthamālā, 1914.

DVN = Daśavaikālikaniryukti of Bhadrabāhu. In Leumann, Ernst. Daśavaikālika with Niryukti. Leipzig: Zeitschrift der Deutschen Morgenländischen Gesellschaft, 1892.

$L T=$ Laghìyastraya of Akalańka Bhaț̣a. In Shastri, Mahendra Kumar. Akalańkagranthatrayam of Sri Bhaț̣ākalan்kadeva. Saraswati Oriental Series 8. Ahmedabad: Saraswati Pustak Bhandar, 1939.

$N K C=$ Nyāyakumudacandra of Prabhācandra. In Nyāyācārya, Mahendra Kumar. Prabhācandra's Nyāyakumudacandra. A Commentary on Bhațțākalañkadeva's Laghìyastraya. Vols. 1 and 2. Bombay: Manikacandra Digambara Jaina Grantha Mālā, 1938-1941.

$N S_{1}=$ Nyāyasūtra of Gautama and $N S B h_{1}=$ Nyāyasūtrabhāṣya of Vātsyāyana. In Angot, Michel. Le Nyāyasūtra de Gautama Akșapāda. Le Nyāyabhāșya d'Akșapāda Pakșilasvāmin. Paris: Les Belles Lettres, 2009.

$N S_{2}=$ Nyāyasūtra of Gautama and $N S B h_{2}=$ Nyāyasūtrabhāṣya of Vātsyāyana. In Jhā, Gañgānāțha. The Nyāyasūtra of Gautama with the Bhāṣya of Vātsyāyana and the Vārtika of Uddyotakara. Vol.1. Delhi: Motilal Banarsidass, 1984.

NSā = Niyamasāra of Kundakunda. In Sain, Uggar. Niyamasāra (The Perfect Law) by Sri Kundakunda Ācārya. Sacred Books of the Jainas 9. Lucknow: Central Jaina Publishing House, 1931.

$N A=$ Nyāyāvatāra of Siddhasena Mahāmati and NAv = Nyāyāvatāravivrttti of Siddharșigaṇi. In Balcerowicz, Piotr. Jaina Epistemology in Historical and Comparative Perspective. Vols. 1 and 2. Stuttgart: Franz Steiner Verlag, 2001.

PrP = Prasannapadā of Candrakīrti. In de La Vallée Poussin, Louis.

Madhyamakavrttiḥ. Mūlamadhyamakakārikās de Nāgārjuna avec la Prasannapadā Commentaire de Candrakīrti. Bibliotheca Buddhica 4. Saint Petersburg: Académie Impériale des Sciences, 1905-1913.

PV = Pramānavārttika and PVsV = Pramānavārttikasvavṛtti of Dharmakīrti. In Gnoli, Ranielo. The Pramānavārttika of Dharmakīrti. The First Chapter with the Auto Commentary. Serie Orientale Roma 23. Rome: Istituto Italiano per il Medio ed Estremo Oriente, 1960.

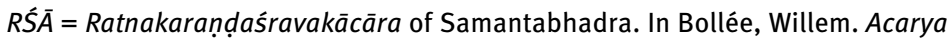
Samantabhadra Ratnakaraṇ̦̣aśravakācāra. Mumbai: Hindi Granth Karyalay, 2012.

SSā = Samayasāra of Kundakunda. In Chakravarti, Appaswami. Ācārya Kundakunda's Samayasāra. New Delhi: Bharatiya Jnanpith, 1950.

TS = Tattvārthasūtra and TSBh = Tattvārthasūtrabhāṣya of Umāsvāti. In Mody, Keshavlal Premchand. Tattvārthādhigamasūtra. Bibliotheca Indica 159. Calcutta: Baptist Mission Press, 1903.

UttS = Uttarādhyayanasūtra. In Jacobi, Herman. Jain Sūtras. Vol. 2. Sacred Books of the East 45. Delhi: Oxford University Press, 1895. 


\section{Secondary Sources}

Balbir, Nalini. “The Perfect Sūtra as Defined by the Jains.” Berliner Indologische Studien 3 (1987): 3-21.

Balcerowicz, Piotr. "The Philosophy of Mind of Kundakunda and Umāsvāti." In The Oxford Handbook of Indian Philosophy, edited by Jonardon Ganeri, 1-13. Oxford: Oxford University Press, 2015.

Balcerowicz, Piotr. "On the Relative Chronology between Samantabhadra and Dharmakīrti." Journal of Indian Philosophy 44 (2016): 437-483.

Balcerowicz, Piotr. "Siddhasena Mahāmati and Akalańka Bhațta: A Revolution in Jaina Epistemology." Journal of Indian Philosophy 44 (2016): 993-1039.

Bilimoria, Purușottama. Śabdapramāna: Word and Knowledge. Studies of Classical India 10. Dordrecht: Kluwer, 1988.

Cort, John. "An Epitome of Medieval Śvetāmbara Jain Literary Culture. A Review and Study of Jinaratnasūri’s Līlāvatīsāra.” International Journal of Jaina Studies 5, no. 1 (2009): 1-33.

Dixit, K. K. Pandit Sukhlalji's Commentary on Tattvārthasūtra of Vācaka Umāsvāti. Lalbhai Dalpatbhai Series 44. Ahmedabad: Lalbhai Dalpatbhai Institute of Indology, 1974.

Eltschinger, Vincent. Penser l'autorité des Écritures. La polémique de Dharmakīrti contre la notion brahmanique orthodoxe d'un Veda sans auteur. Autour de Pramānavarttika 1. 213-268 et Svavrtti. Beiträge zur Kultur und Geistesgeschichte Asiens 56. Vienna: Verlag der Österreichischen Akademie der Wissenschaften, 2007.

Fujinaga, Sin. "Determining Which Jaina philosopher Was the Object of Dharmakīti's criticisms." Philosophy East and West 50, no. 3 (2000): 378-384.

Fujinaga, Sin. "Why Must There Be an Omniscient in Jainism?" In Studies in Jaina History and Culture. Disputes and Dialogue, edited by Peter Flügel, 107-116. London: Routledge Advances in Jain Studies, 2006.

Jyväsjärvi, Mari. "Retrieving the Hidden Meaning: Jain Commentarial Techniques and the Art of Memory." Journal of Indian Philosophy 38 (2010): 133-162.

McClintock, Sarah. Omniscience and the Rhetoric of Reason. Śāntarakșita and Kamalaśila on Rationality, Argumentation and Religious Authority. Boston: Wisdom, 2010.

Qvarnström, Olle. "Stability and Adaptability: A Jain Strategy for Survival and Growth." Indo-Iranian Journal 41 (1998): 33-55.

Qvarnström, Olle. "The Jain-Mīmāṃsā Debate on Omniscience”. In Studies in Jaina History and Culture. Disputes and Dialogue, edited by Peter Flügel, 89-106. London: Routledge Advances in Jain Studies, 2006.

Radhakrishnan, Sarvepalli. Indian Philosophy. Vol. 2. London: Georges Allen \& Unwin, 1923.

Shah, Nagin J. Akalañka's Criticism of Dharmakīrti Philosophy. A Study. Lalbhai Dalpatbhai Series 11. Ahmedabad: Lalbhai Dalpatbhai Institute of Indology, 1967.

Shastri, Indra Chandra. Jaina Epistemology. Parshwanath Vidyapeeth Research Series 50. Varanasi: Parshwanath Vidyapeeth Research Institute, 1990.

Soni, Jayandra. "The Notion of Āpta in Jaina Philosophy." In South Asian Studies Papers 17. Jain Doctrine and Practice: Academic Perspectives, edited by Joseph T. 0'Connell, 50-68. Toronto: Centre for South Asian Studies, 2000. 